\title{
Pola Penyelenggaraan Konsep Triple Helix dalam Penyediaan Sumber Daya Manusia Pengelola Pabrik Kelapa Sawit Indonesia
}

\author{
Idad Syaeful $\mathrm{Haq}^{1 *}$, Lia Laila ${ }^{1}$ \\ ${ }^{1}$ Program Studi Teknologi Pengolahan Sawit, Fakultas Vokasi, Institut Teknologi dan Sains Bandung \\ ${ }^{1}$ Corresponding author: idadshaq@itsb.ac.id
}

\begin{abstract}
Abstrak. Konsep triple helix merupakan jalinan peran kerjasama ketiga aktor dalam penciptaan pengetahuan (knowledge creation) yang terdiri Akademisi, Bisnis dan Pemerintah. Penerapan konsep ini dalam pengembangan industri sawit nasional sudah mulai diterapkan, hal ini mengacu kepada posisi Indonesia sebagai negara produsen minyak mentah sawit terbesar di dunia. Hingga kini telah diidentifikasi bahwa salahsatu kelemahan utama pengembangan sawit nasional adalah ketidakmampuan untuk mengubah produk berbasis keunggulan komparatif yang dimiliki menjadi produk keunggulan kompetitif yang memiliki nilai tambah yang lebih besar. Peran pemerintah sebagai fasilitator dan regulator dalam mengatasi kendala dan persoalan industri sawit seperti diuraikan di atas, salah satu upayanya adalah memberikan mandat (penugasan) kepada ITSB (sebagai salah satu aktor akademisi) untuk membuka Program Studi Teknologi Pengolahan Sawit (TPS) jenjang diploma tiga (D-3). Penugasan ini merupakan salahsatu solusi dalam penyediaan sumber daya manusia dalam pengelolaan teknologi di industri pengolahan sawit. Keinginan pemerintah ini tidak lain agar industri sawit nasional ke depan semakin memiliki daya saing. Model pemberian tugas pembukaan Prodi TPS jenjang D-3 yang dimandatkan kepada ITSB merupakan kepercayaan yang diberikan pemerintah kepada ITSB. Hasil luaran penelitian adalah teridentifikasinya pola penyelenggaraan kerjasama antara pihak pemerintah, akademisi dan bisnis dalam penyediaan sumber daya manusia pengelola Pabrik Kelapa Sawit. Sedangkan tindakan teknologis yang diperlukan berkaitan penyediaan SDM sawit nasional, di antaranya diperlukan komunikasi dan koordinasi yang lebih intens agar kompetensi yang diminta pihak industri (pabrik kelapa sawit) dapat terpenuhi dengan baik. Salah satu solusinya adalah dibentuk wadah kelembagaan (lembaga intermediasi) yang menghubungkan kepentingan industri dengan pihak akademisi. Kontribusi penelitian ini dalam pengembangan ilmu adalah memberikan suatu gambaran atau pola penyelenggaraan mengenai kerjasama tiga aktor dalam penyiapan sumber daya manusia pengelola industri sawit.
\end{abstract}

Keywords: TripleHelix, Kelapa Sawit, Sumber Daya Manusia

\section{Pendahuluan}

Model inovasi triple helix dapat diterapkan guna mendongkrak produktivitas komoditas kelapa sawit Indonesia yang belum berdaya saing tinggi. Hingga tahun 2011, Oil World masih mencatat Indonesia sebagai produsen CPO nomor satu di dunia dengan volume produksi sebesar 23.9 juta ton CPO per tahun, atau lebih besar sekitar 5 juta ton dari Malaysia yang berada di urutan kedua. Hanya sangat disayangkan, 65 persen dari 23,9 juta ton produksi CPO Indonesia tersebut masih berupa produk minyak mentah, bukan produk olahan bernilai tambah tinggi. Ini berbanding terbalik dengan Malaysia, dimana justru 85\% CPOnya tampil dalam bentuk produk olahan.

Indonesia perlu mengembangkan industri hilir kelapa sawit. Produk-produk turunan bernilai tambah tinggi perlu diciptakan, melalui inovasi terhadap jutaan ton minyak mentah tadi, guna meningkatkan nilai tambahnya. Sedikitnya terdapat 23 jenis produk turunan hilir yang dapat dikembangkan dari industri kelapa 
sawit, seperti margarin, shortening, cocoa butter substitutes, vanaspati, atau vegetable ghee, di samping produk industri nonpangan seperti oleikimia (fatty acid, fatty alcohol, atau gliserin).

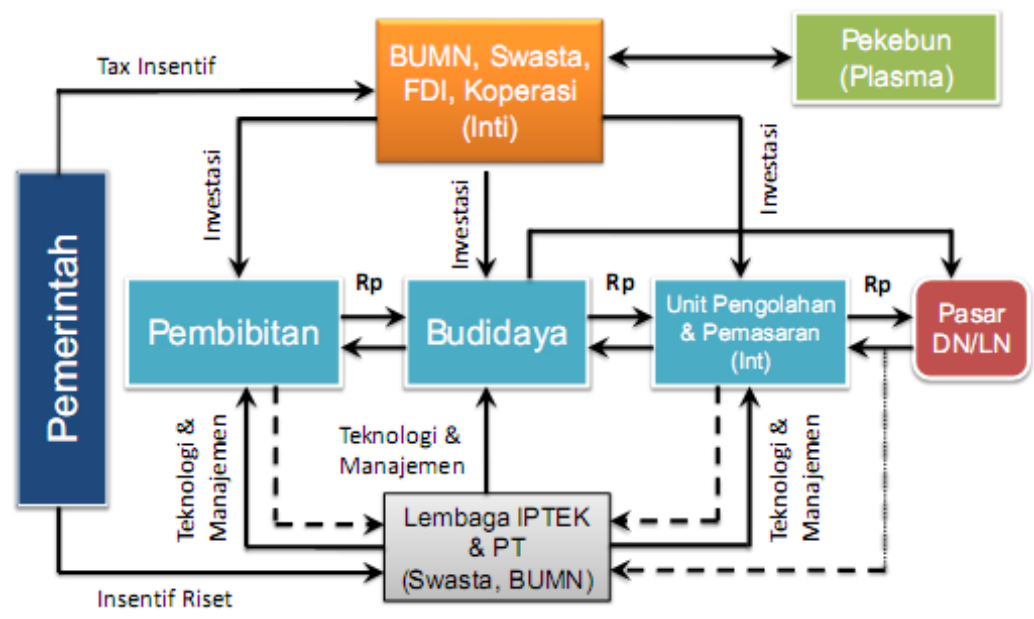

Gambar 33. Model sistem inovasi komoditas kelapa sawit

(Sumber: Zuhal, 2013)

Pengembangan industri hilir kelapa sawit tentu memerlukan sinergi berbagai pihak mengingat luasnya skala tantangan yang dihadapi. Ini, antara lain, meliputi kurangnya ketersediaan infrastruktur fisik yang memadai termasuk penyediaan teknologi industri dan transportasi, kurangnya ketersediaan SDM berkualitas di bidang industri kelapa sawit termasuk sarana litbang dan invensi-invensi yang prospektus, kurangnya kebijakan yang suportif baik di level nasional dan terutama lokal, atau kurangnya pendanaan untuk produksi skala komersial (Zuhal, 2013).

Berikut ditampilkan secara skematik model implementasi kerjasama ketiga aktor konsep triple helix dalam penyediaan SDM industri sawit nasional. Adapun peran masing-masing dari ketiga aktor, yaitu Pemerintah dalam hal ini diwakili oleh kelembagaan Direktorat Jenderal Pendidikan Tinggi (Ditjen Dikti, Kemendikbud). Akademisi oleh ITSB sebagai penyelenggara pendidikan yang menyiapkan dan menyediakan SDM dalam bentuk kesediaan membuka Program Studi Teknologi Pengolahan Sawit jenjang Diploma Tiga (D-3). Bisnis/industri yang diwakili oleh PT. Smart Tbk. menyediakan fasilitas beasiswa ikatan dinas selama menempuh studi di Prodi TPS (tiga tahun) dan beasiswa biaya hidup untuk mahasiswa yang berprestasi akademik di atas rata-rata, serta penempatan kerja di Pabrik Kelapa Sawit milik PT. Smart Tbk. ketika lulus dari program pendidikan yang telah dijalaninya.

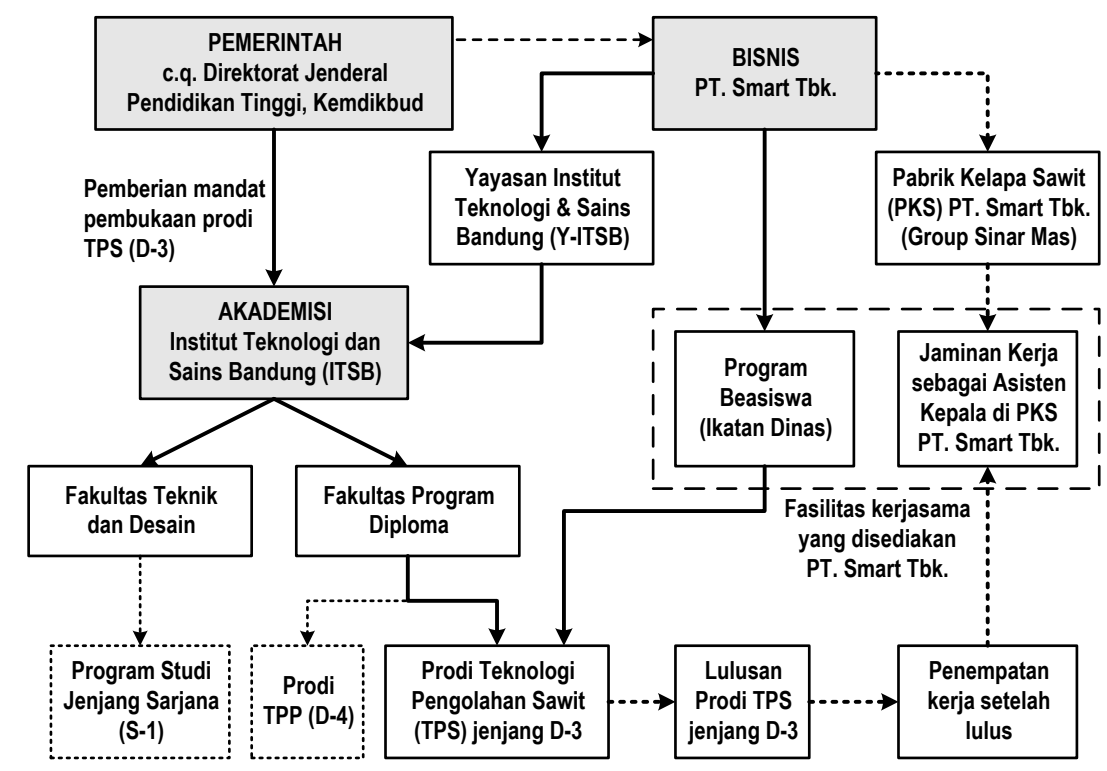

Gambar 34. Visualiasi skematik implementasi kerjasama antara aktor pemerintah, akademisi dan bisnis dalam penyediaan SDM Pabrik Kelapa Sawit (Sumber: Dokumen ITSB 2011, diolah) 


\section{Pendekatan dan Metode}

Pendekatan penelitian ini menggunakan gabungan (integrasi) antara pendekatan deduktif (from the whole to part) dan pendekatan induktif (from the part to the whole). Pendekatan deduktif digunakan untuk membangun hipotesis (kesimpulan awal) yang dibangun dari teori-teori yang ada. Hipotesis ini akan menjadi arah panduan dalam mengidentifikasi variabel-variabel pembentuk dari fenomena yang menjadi pengamatan (tahap observasi) yang selanjutnya bermuara kepada tahap verifikasi (konfirmasi) atau pengecekan data di lapangan. Selanjutnya digunakan pendekatan induktif untuk melihat pola keterkaitan (pattern) di antara variabel-variabel pembentuk yang telah berhasil diidentifikasi dan diverifikasi tersebut, sehingga obyek materi penelitian dapat diketahui dengan baik strukturnya. Berdasarkan pola keterkaitan (struktur) kemudian akan bermuara kepada generalisasi atau model yang dibentuk dari hasil penelitian ini. Berikut ditampilkan visualisasi skematik integrasi pendekatan antara deduktif dan induktif.

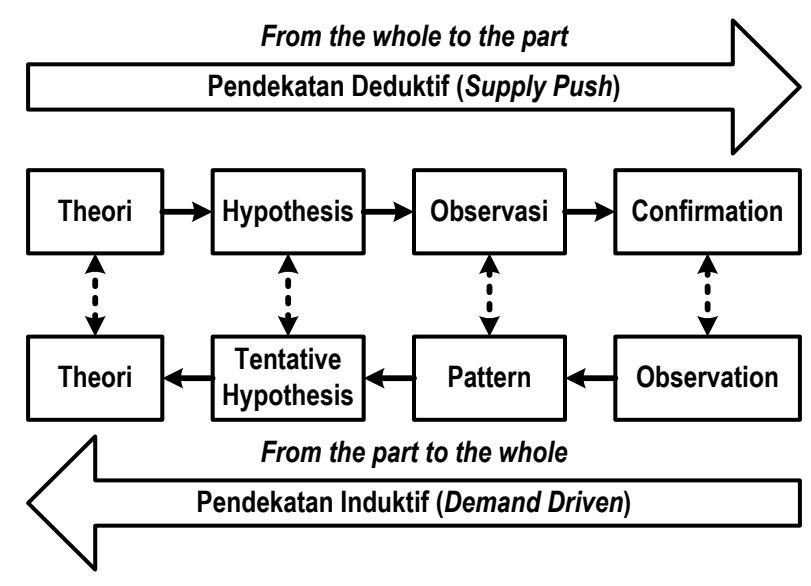

Gambar 35. Integrasi pendekatan antara deduktif dan induktif

Berdasarkan pendekatan penelitian yang telah diuraikan di atas, maka model penelitian yang digunakan termasuk ke dalam model penelitian deskriptif. Model penelitian ini (deskriptif) berusaha untuk menggambarkan dan menginterpretasi obyek sesuai dengan apa adanya (Best dalam Darmadi H, 2011). Penggambaran dan penginterpretasian obyek didasarkan kepada data kualitatif yang diperoleh. Tahapan penelitian ini ditampilkan dalam skematik berikut.

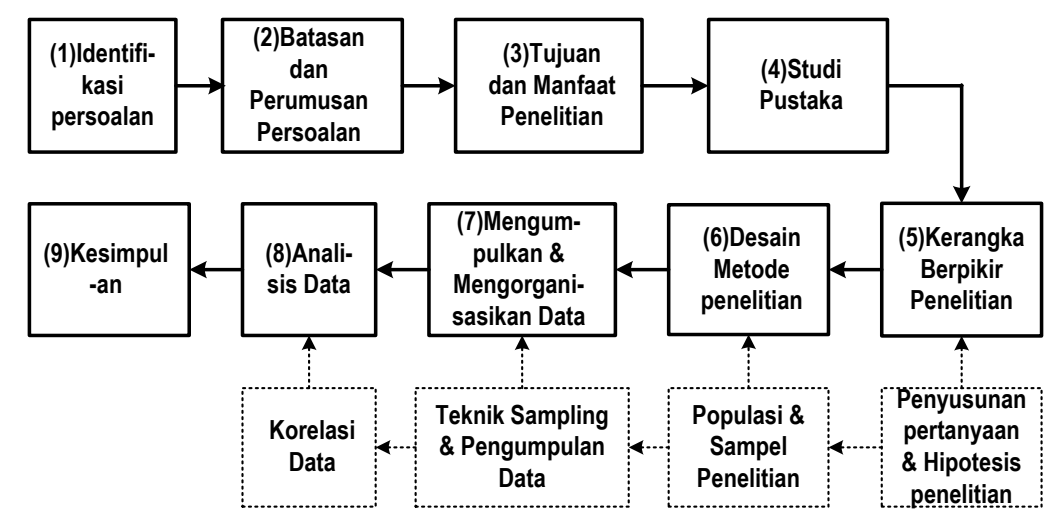

Gambar 36. Tahapan penelitian

Adapun pemerolehan data kualitatif ini mengacu kepada rancangan penelitian yang mencakup penentuan populasi, sampel dan teknik sampling, serta teknik pengumpulan data sebagaimana dijelaskan pada bagian berikut.

\subsection{Rancangan penelitian}

Mengacu kepada teori yang digunakan kemudian dibangun hipotesis penelitian, yaitu bahwa ITSB sebagai aktor akademisi dalam implementasi kerja sama dengan pihak industri berdasarkan konsep triple helix telah 
berhasil memenuhi harapan dan keinginan pihak industri (PT. Smart. Tbk.) dalam penyediaan SDM pengelola pabrik kelapa sawit.

Pertanyaan penelitian ini disusun sebagai pedoman dalam melakukan pengambilan data penelitian. Adapun teknik pengampilan data dilakukan melalui penyebaran kuesioner kepada para alumni, wawancara kepada pihak industri pengguna alumni (manajer/kepala pabrik, asisten kepala pabrik dan para asisten) pabrik kelapa sawit. Pertanyaan kuesioner dan wawancara disusun berdasarkan garis-garis besar isi kuesioner dan wawancara sebagaimana ditunjukkan pada tabel berikut.

Tabel 18. Pedoman pertanyaan penelitian

\begin{tabular}{|c|c|}
\hline Teknik Pengampilan Data & Garis-Garis Besar Isi Kuesioner dan Wawancara \\
\hline (1)Kuesioner untuk alumni & $\begin{array}{l}\text { (1) Bidang pekerjaan yang dijabat sekarang dan periode } \\
\text { lama waktu untuk memperolehnya; } \\
\text { (2) Tantangan \& hambatan dalam penempatan bekerja di } \\
\text { pabrik kelapa sawit; } \\
\text { (3) Situasi di tempat kerja, apakah atasan atau teman } \\
\text { sekerja memberikan bimbingan atau arahan; } \\
\text { (4) Kelompok mata kuliah yang mendukung bidang dan } \\
\text { posisi pekerjaan sekarang; } \\
\text { (5) Bidang peminatan dan topik Tugas Akhir ketika kuliah; } \\
\text { (6) Berkaitan dengan penerapan kemampuan } \\
\text { umum/manajerial dan teknis alumni di pabrik sawit. }\end{array}$ \\
\hline $\begin{array}{l}\text { (2)Wawancara untuk Kepala } \\
\text { Pabrik/manajer pabrik }\end{array}$ & $\begin{array}{l}\text { (1) Kesesuaian alumni dengan bidang pekerjaan yang } \\
\text { dijabat sekarang dan periode lama waktu untuk } \\
\text { memperolehnya; } \\
\text { (2) Penilaian tantangan \& hambatan alumni dalam } \\
\text { penempatan bekerja di pabrik kelapa sawit; } \\
\text { (3) Penilaian apakah alumni masih memerlukan bimbingan } \\
\text { dan arahan ketika bekerja dan berapa periode lama } \\
\text { waktu yang diperlukan untuk hal ini; } \\
\text { (4) Berkaitan dengan penerapan kemampuan } \\
\text { umum/manajerial dan teknis alumni di pabrik sawit. }\end{array}$ \\
\hline
\end{tabular}

Penentuan populasi, sampel dan teknik sampling, serta teknik pengumpulan data dijelaskan sebagai berikut.

1) Populasi

Sesuai jumlah alumni, yaitu 13 orang yang tersebar di 13 Pabrik Kelapa Sawit (PKS) milik PT. Smart, Tbk.

2) Sampel

Difokuskan pada zonasi I, yaitu Sumatera, kepulauan Riau, Bangka dan Lampung (di zona-I terdapat 8 buah PKS)

3) Teknik Sampling

Ditetapkan 3 sampel PKS, dengan teknik pemilihan purposive sampling. Dimana pemilihan teknik sampling ini bertujuan untuk mengetahui sampel PKS di Zona-I, yaitu PKS skala besar (PKS Medan \& Palembang) dan PKS skala sedang (PKS Lampung)

Teknik pengumpulan data dan justifikasinya dijelaskan pada tabel berikut.

Tabel 19. Teknik pengumpulan data dan justifikasinya

\begin{tabular}{|l|l|}
\hline Teknik Pengumpulan Data & Justifikasi Teknik yang digunakan \\
\hline (1)Penyebaran Angket/ kuesioner & $\begin{array}{l}\text { Diperlukan untuk mendapatkan data kuantitatif } \\
\text { atas beberapa pertanyaan yang diajukan melalui } \\
\text { angket/kuesioner }\end{array}$ \\
\hline (2)Wawancara & $\begin{array}{l}\text { Diperlukan agar diperoleh gambaran yang utuh, } \\
\text { komprehensif dan mendalam dari para } \\
\text { stakeholder }\end{array}$ \\
\hline (3)Observasi & $\begin{array}{l}\text { Diperlukan untuk mengetahui \& memahami } \\
\text { dokumen-dokumen yang melandasi } \\
\text { penyelenggaraan kerjasama di antara } \\
\text { pelaku/stakeholder (Akademisi-Industri- } \\
\text { Pemerintah) }\end{array}$ \\
\hline
\end{tabular}




\subsection{Lokasi Penelitian}

Dari sebaran data alumni sebanyak tigabelas orang yang tersebar di delapan lokasi Pabrik Kelapa Sawit (PKS) di seluruh Indonesia, untuk tahap pertama penelitian difokuskan untuk wilayah Sumatera, yaitu PKS yang berlokasi di Provinsi Lampung (1 pabrik), Medan (1 pabrik) dan Palembang (1 pabrik). Diharapkan dari kedua sampel lokasi penelitian ini sudah tergambarkan pola kerjasama untuk Zona-I (Sumatera, Kep. Riau, Bangka \& Lampung). Sedangkan tahap kedua untuk wilayah Kalimantan (Tengah dan Selatan) sebagai Zona-II. Adapun responden yang terdapat di pabrik tersebut adalah kepala pabrik dan asisten kepala pabrik yang mewakili pengguna (pihak industri) dari lulusan Prodi TPS ITSB dan para alumni Prodi TPS ITSB yang bekerja di lokasi PKS tersebut.

\section{Hasil dan Pembahasan}

\subsection{Hasil Penelitian}

Hasil penelitian yang diperoleh terbagi dalam 2 (dua) kategori, sebagaimana tujuan yang dibangun dalam penelitian ini, yaitu: (a)Bagaimana peran dan kontribusi ITSB dalam penyediaan SDM pengelola Pabrik Kelapa Sawit (PKS) di Indonesia, serta (b)Bagaimana pola penyelenggaraan kerjasama yang telah dibangun antara pihak Akademisi (ITSB) dan pihak Industri (PT. Smart, Tbk.). Unsur-unsur pembentuk yang mencakup peran dan kontribusi unsur akademik (kampus) dalam penyediaan SDM pengelola PKS yang dibangun terdiri atas: (1)Unsur Kurikulum Prodi Teknologi Pengolahan Sawit (TPS) jenjang D-3; (2)Unsur Penyelenggaraan/implementasi proses pembelajaran di Prodi TPS jenjang D-3; (3)Unsur Kompetensi Lulusan yang dihasilkan dari Prodi TPS jenjang D-3; (4)Unsur Kompetensi SDM Pengelola PKS tuntutan pihak industri (PT. Smart, Tbk.).

Selanjutnya kategori bagaimana pola penyelenggaraan kerjasama di antara pihak akademisi (ITSB) dan pihak Industri (ITSB), hal ini dapat diketahui dengan melakukan korelasi/keterkaitan di antara unsur-unsur pembentuk yang telah disebutkan di atas. Sehingga atas dasar ini, maka pola penyelenggaraan kerjasama yang dibangun di antara kedua pihak ini (Akademisi/ITSB dan Industri/PT. Smart, Tbk.) dapat diketahui dengan baik. Berikut ditampilkan visualisasi skematik unsur-unsur pembentuk untuk mengetahui pola penyelenggaraan kerjasama yang dibangun antara akademisi dan industri tersebut yang digambarkan dengan pendekatan manufaktur (input-proses-output).

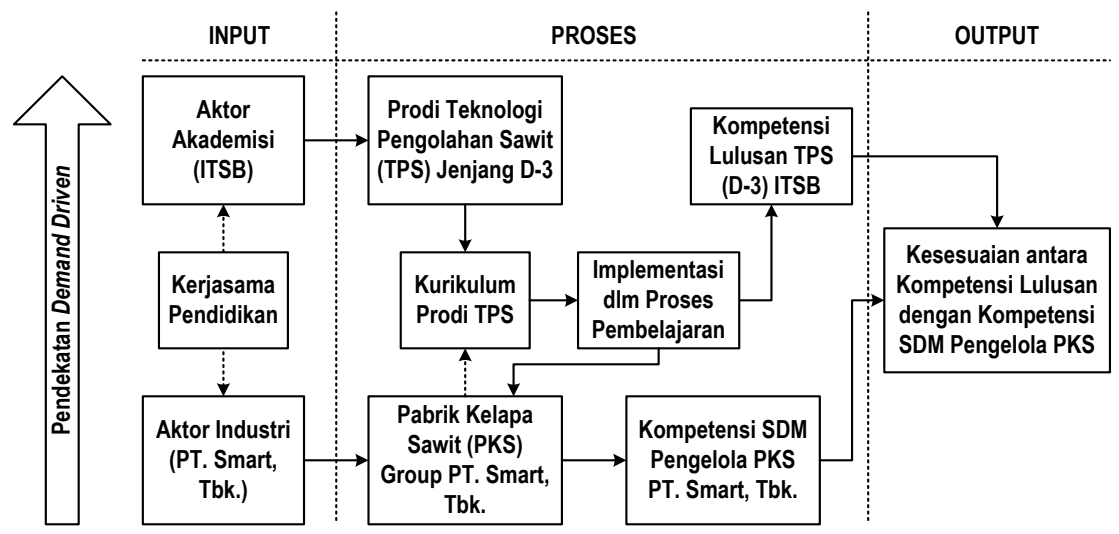

Gambar 37. Unsur-unsur pembentuk pola penyelenggaraan kerjasama

1) Unsur Kurikulum Prodi Teknologi Pengolahan Sawit (TPS) Jenjang D-3

Kurikulum Prodi TPS jenjang D-3 dibangun berdasarkan permintaan dari pihak industri, dengan kompetensi yang diminta terdiri atas Kompetensi Manajerial dan Kompetensi Teknis. Kompetensi lulusan Diploma Tiga yang diminta pihak industri nantinya akan menempati posisi jabatan Asisten (setingkat Supervisor atau level tiga) di lingkungan kerja Pabrik Kelapa Sawit PT. Smart, Tbk. Adapun hierarki jabatan di Pabrik Kelapa Sawit terdiri atas: (a)Manajer atau Kepala Pabrik, (b)Asisten Manajer (Asisten Kepala Pabrik/Askep) dan (c)Para Asisten sebagaimana ditunjukkan pada visualisasi skematik sebagai berikut. 


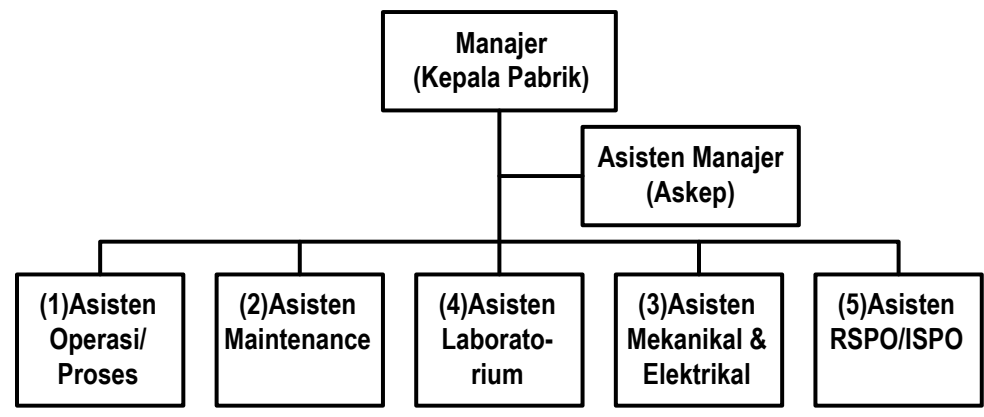

Gambar 38. Struktur organisasi jabatan di Pabrik Kelapa Sawit

Adapun uraian perincian kedua kompetensi yang diminta sebagaimana ditampilkan pada tabel berikut.

Tabel 20. Kompetensi Manajerial dan Teknis lulusan yang diminta

\begin{tabular}{|c|c|}
\hline Jenis Kompetensi & Elemen-Elemen Kompetensi \\
\hline $\begin{array}{l}\text { (a)Kompetensi Manajerial/ } \\
\text { Umum }\end{array}$ & $\begin{array}{l}\text { (1)Menerapkan Nilai-nilai Perusahan; } \\
\text { (2)Melakukan Komunikasi; } \\
\text { (3)Melakukan Analisis; } \\
\text { (4)Menciptakan Iklim Kerja yang Positif; } \\
\text { (5)Meraih Standar Kerja Tertinggi; } \\
\text { (6)Melakukan Pengawasan Operasional; } \\
\text { (7)Mengambil Tindakan. }\end{array}$ \\
\hline (b)Kompetensi Teknis & $\begin{array}{l}\text { (1)Mengawasi Proses Pengolahan Sawit } \\
\text { (2)Mengawasi Pembangkit Tenaga; } \\
\text { (3)Memeriksa Kualitas dan Kuantitas Produk; } \\
\text { (4)Mengelola Pengolahan Air; } \\
\text { (5)Memelihara serta Memperbaiki Mesin-Mesin; } \\
\text { (6)Melakukan Administrasi Pabrik. }\end{array}$ \\
\hline
\end{tabular}

Atas dasar kompetensi yang telah ditetapkan oleh pengguna lulusan ini (yaitu pihak industri/Pabrik Kelapa Sawit), maka penyusunan kurikulum Prodi TPS bisa dikatakan menggunakan pendekatan Demand Driven (permintaan pasar yang menggerakkan). Visualisasi skematik pendekatan ini ditunjukkan pada gambar berikut.

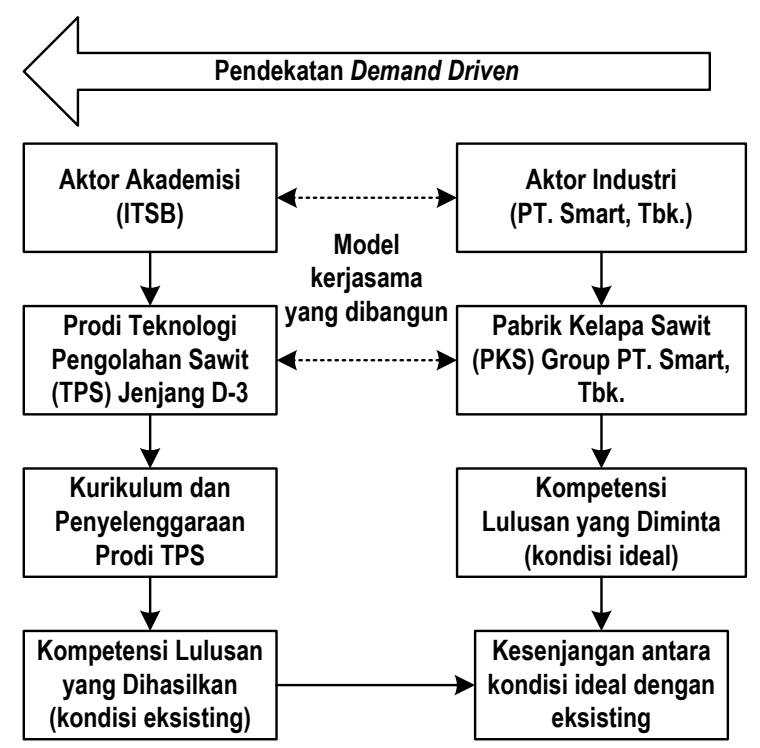

Gambar 39. Pendekatan demand driven dalam penyusunan kurikulum 
Hal ini berarti di dalam penyusunan kurikulum Prodi TPS ini akan didasarkan kepada kompetensi yang telah ditetapkan oleh pihak pengguna (industri), yaitu kurikulum yang dikhususkan untuk industri/pabrik pengolah sawit (specially dedicated to palm oil industry). Dengan mengacu kepada kompetensi yang telah ditetapkan industri ini, kemudian diturunkan kepada kelompok mata kuliah yang mendukung kepada terbentuk kompetensi yang diminta tersebut. Kelompok matakuliah yang mendukung kepada kompetensi tersebut mencakup beberapa bidang, yaitu: (1)material, (2)perawatan mesin, (3)teknologi manufaktur, (4)manajemen industri, (5)mesin konversi energi, (6)pengolahan sawit, dan (7)kualitas minyak sawit mentah (Crude Palm Oil/CPO). Ketujuh bidang mata kuliah berserta keterkaitan dengan kompetensi digambarkan sebagai berikut.

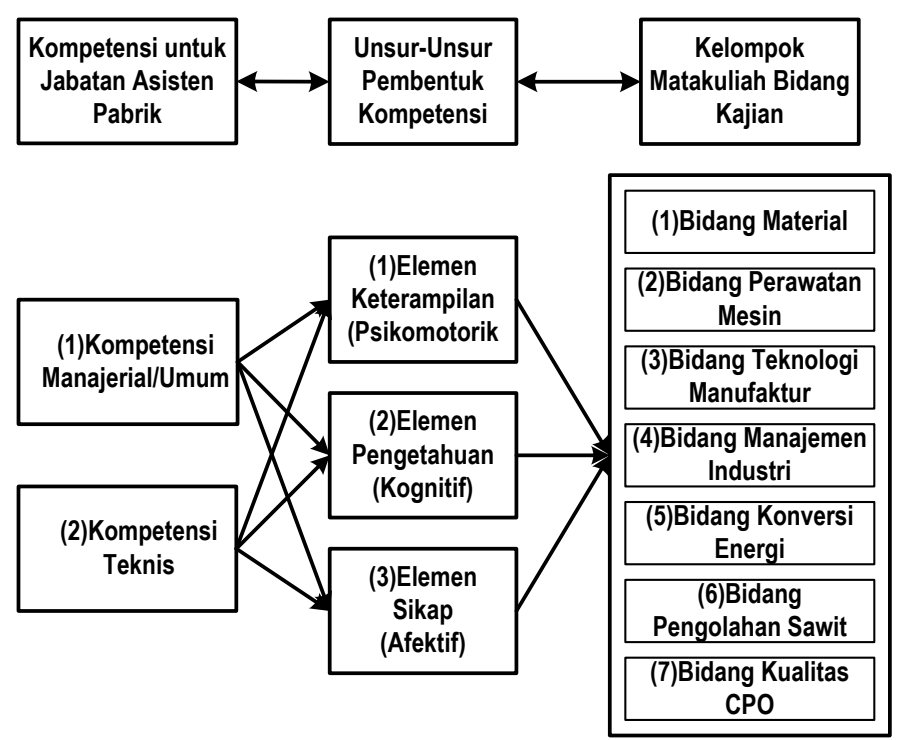

Gambar 40. Keterkaitan kompetensi dan bidang kajian

Ketujuh bidang kelompok mata kuliah kemudian diturunkan kepada rincian sejumlah mata kuliah dengan jumlah total SKS yang harus ditempuh untuk menyelesaikan studi jenjang diploma tiga sebanyak 112 SKS. Jenjang pendidikan diploma termasuk ke dalam jenis pendidikan vokasi, sehingga penguasan ranah keterampilan (aspek psikomotorik) menjadi prioritas pada jenjang pendidikan ini. Atas dasar ini kemudian pembagian komposisi antara penguasaan aspek praktik dibuat lebih dominan dibanding penguasaan aspek teori/pengetahuan.

2) Unsur Proses Penyelenggaraan/Pembelajaran (Implementasi Kurikulum) Prodi TPS jenjang D-3 Unsur-unsur yang membangun proses penyelenggaraan/ pembelajaran mencakup implementasi dari model kurikulum Program Studi Teknologi Pengolahan Sawit (TPS) jenjang Diploma Tiga yang telah disusun oleh unsur akademisi (dosen tetap prodi) dengan pihak industri (PT. Smart, Tbk.). Implementasi model kurikulum yang tetap melibatkan pihak industri di antaranya adalah: (a)Pembekalan materi dari praktisi lapangan (dari unsur pabrik kelapa sawit); (b)Kerja praktik lapangan di pabrik kelapa sawit;(c)Magang industri; (d)Topik Tugas Akhir (TA) industri kelapa sawit.

Materi pembekalan yang diberikan pihak industri di antaranya adalah: (a)Materi Keselamatan dan Kesehatan Kerja (K3) dari praktisi pabrik; (b)Materi yang berkaitan dengan Kelapa Sawit Berkelanjutan atau SPO/RSPO (Sustainable Palm Oil/Rountable Sustainable Palm Oil).

Kerja Praktik (KP) dilakukan sebanyak 2 (dua) kali, yaitu: (a)Kerja Praktik Satu (KP-1) dilakukan mahasiswa mahasiswa pada akhir Semester 2 (mahasiswa tingkat satu) selama 2 (dua) bulan untuk mengenalkan mahasiswa pada proses pengolahan sawit menjadi minyak sawit dan lingkungan kerja di pabrik kelapa sawit. (b)Kerja Praktik Dua (KP-2) dilakukan mahasiswa mahasiswa pada akhir Semester 4 (mahasiswa tingkat dua) selama 2 (dua) bulan untuk lebih memahami dan mendalami proses pengolahan sawit menjadi minyak sawit dan lingkungan kerja di pabrik kelapa sawit.

Sedangkan Magang Industri dilakukan mahasiswa tingkat akhir (tingkat tiga) pada Semester 6 selama 4 (empat) bulan. Tujuan dilakukan Magang Industri adalah agar mahasiswa semakin matang dan adaptif 
dengan lingkungan pabrik sawit. Pada kegiatan ini diharapkan mahasiswa mencari topik Tugas Akhir (TA) dan pengumpulan data TA hal-hal yang berkaitan dengan persoalan-persoalan teknis dan nyata (riel) di pabrik sawit. Selama Magang ini mahasiswa intens berhubungan dengan Pembimbing TA di kampus untuk melakukan bimbingan dan konsultasi pengumpulan data topik TA ini. Pada akhir periode Magang ini, Pembimbing TA melakukan kunjungan lapangan untuk melakukan pengawasan (Supervisi) terhadap pelaksanaan Magang mahasiswa tugas akhir ini. Di dalam pelaksanaan Magang ini, pihak industri sudah memperlakukan mahasiswa sebagai pegawai yang magang dan diberi beberapa tanggung jawab pekerjaan setingkat Asisten.

Topik Tugas Akhir mahasiswa wajib berkaitan dengan solusi pemecahan persoalan yang ditemukan pada saat melakukan Magang di pabrik kelapa sawit. Tabel berikut merangkumkan pelaksanaan kegiatankegiatan dan hasil yang diharapkan berkaitan dengan kerja sama proses penyelenggaraan pembelajaran yang dilakukan bersama pihak industri (pabrik kelapa sawit). Penyelesaian TA ini dilaksanakan pada Semester 6 dengan penilaian topik TA melibatkan juga penilaian dari unsur pihak industri (pabrik kelapa sawit).

3) Unsur Pengecekan Kesesuaian antara Kompetensi Lulusan yang dihasilkan dengan tuntutan pihak industri (PT. Smart, Tbk.).

Pada bagian ini dilakukan pengecekan kesesuaian/korelasi antara kompetensi lulusan Prodi TPS yang dihasilkan dengan kompetensi tuntutan dari pihak industri. Pengecekan kesesuaian dilakukan dengan melakukan analisis korelasi terhadap data hasil kuesioner dan wawancara yang telah diperoleh. Data hasil kuesioner dan wawancara ini ditampilkan pada tabel berikut.

a) Hasil Kuesioner terhadap Alumni

Berikut gambaran lengkap hasil pengolahan kuesioner yang dilakukan terhadap alumni.

Tabel 21. Hasil pengolahan kuesioner

\begin{tabular}{|l|l|}
\hline \multicolumn{1}{|c|}{ Jenis Pertanyaan } & \multicolumn{1}{c|}{ Hasil } \\
\hline $\begin{array}{l}\text { (1)Bidang pekerjaan yang dijabat } \\
\text { sekarang dan periode lama waktu untuk } \\
\text { memperolehnya }\end{array}$ & $\begin{array}{l}\text { Asisten Operasi, Asisten Laboratorium dan Officer } \\
\text { SPO/RSPO. } \\
\text { Periode lama waktu antara 3-12 bulan. }\end{array}$ \\
\hline $\begin{array}{l}\text { (2)Tantangan \& hambatan dalam } \\
\text { penempatan bekerja di pabrik kelapa } \\
\text { sawit }\end{array}$ & $\begin{array}{l}\text { Masalah adaptasi, standar kerja, iklim kerja serta } \\
\text { inisiatif tindakan }\end{array}$ \\
\hline $\begin{array}{l}\text { (3)Situasi di tempat kerja, apakah atasan } \\
\text { atau teman sekerja memberikan } \\
\text { bimbingan atau arahan }\end{array}$ & $\begin{array}{l}\text { Mendapat arahan dan bimbingan. } \\
\text { Dari Kepala Pabrik, Askep dan Asisten lainnya. }\end{array}$ \\
\hline $\begin{array}{l}\text { (4)Kelompok mata kuliah yang } \\
\text { mendukung bidang dan posisi pekerjaan } \\
\text { sekarang }\end{array}$ & Konversi energi, operasi mesin, kualitas produk \\
\hline $\begin{array}{l}\text { (5)Bidang peminatan dan topik Tugas } \\
\text { Akhir ketika kuliah }\end{array}$ & $\begin{array}{l}\text { Terdapat keragaman/ variasi antara bidang } \\
\text { peminatan dengan topik TA }\end{array}$ \\
\hline $\begin{array}{l}\text { (6)Berkaitan dengan penerapan } \\
\text { kemampuan umum/manajerial dan } \\
\text { teknis alumni di pabrik sawit. }\end{array}$ & $\begin{array}{l}\text { Semua kemampuan umum dirasa penting. } \\
\text { Baru sebagian kemampuan umum yang dikuasai } \\
\text { dengan baik. Semua kemampuan umum dirasa } \\
\text { sangat sulit diterapkan }\end{array}$ \\
\hline
\end{tabular}

b) Hasil Wawancara terhadap Kepala Pabrik/Manajer dan Asisten Kepala Pabrik (Askep) Berikut gambaran lengkap hasil pengolahan wawancara tersebut.

Tabel 22. Hasil pengolahan wawancara

\begin{tabular}{|c|c|}
\hline Jenis Pertanyaan & Hasil \\
\hline $\begin{array}{l}\text { Kesesuaian alumni dengan bidang } \\
\text { pekerjaan yang dijabat sekarang dan } \\
\text { periode lama waktu untuk } \\
\text { memperolehnya }\end{array}$ & $\begin{array}{l}\text { Sudah terdapat kesesuaian bidang pekerjaan. } \\
\text { Kemampuan Teknis dinilai masih kurang. }\end{array}$ \\
\hline
\end{tabular}




\begin{tabular}{|l|l|}
\hline $\begin{array}{l}\text { Penilaian tantangan \& hambatan alumni } \\
\text { dalam penempatan bekerja di pabrik } \\
\text { kelapa sawit }\end{array}$ & Inisitiaf tindakan dan leadership perlu ditingkatkan. \\
\hline $\begin{array}{l}\text { Penilaian apakah alumni masih } \\
\text { memerlukan bimbingan dan arahan } \\
\text { ketika bekerja dan berapa periode lama } \\
\text { waktu yang diperlukan untuk hal ini }\end{array}$ & $\begin{array}{l}\text { Masih diperlukan pembimbingan dan arahan dari } \\
\text { atasan atau senior orang pabrik. } \\
\text { Lama waktu bervariasi. }\end{array}$ \\
\hline $\begin{array}{l}\text { Berkaitan dengan penerapan } \\
\text { kemampuan umum/manajerial dan } \\
\text { teknis alumni di pabrik sawit. }\end{array}$ & Kemampuan umum sudah baik. \\
\hline
\end{tabular}

\subsection{Analisis Pembahasan}

Berdasarkan tabel di atas berikut beberapa analisis yang dapat diberikan, yaitu:

1) Berkaitan dengan bidang pekerjaan yang dijabat sekarang dan periode lama waktu untuk memperolehnya. Terdapat jabatan baru setara asisten, yaitu Officer SPO/RSPO dimana jabatan ini membutuhkan penguasan terhadap standar K3 (Keselematan dan Kesehatan Kerja) dan kemampuan berpikir integrasi karena tuntutan jabatan ini adalah menggabungkan beberapa data dari mulai aspek hulu sampai dengan hilir dari proses pengolahan sawit (budidaya tanaman sawit hingga penyimpanan minyak sawit).

2) Umumnya tantangan \& hambatan yang dirasa berat dalam penempatan kerja pertama kali di pabrik kelapa sawit adalah masalah standar kerja, iklim kerja serta inisiatif tindakan. Masalah adaptasi tidak menjadi persoalan, karena alumni sudah memahami lingkungan kerja pabrik kelapa sawit (sudah terbiasa).

3) Staf lingkungan pabrik (Kepala Pabrik, Askep dan Asisten lainnya) telah memberikan bimbingan dan arahan kepada para alumni.

4) Kelompok mata kuliah yang diberikan di kampus sudah mendukung terhdap bidang dan posisi pekerjaan yang dijabat sekarang.

5) Masih terdapat keragaman antara bidang peminatan kelompok mata kuliah dan topik Tugas Akhir dengan jabatan pekerjaan yang diemban ketika pertama kali bekerja.

Sedangkan analisis yang berkaitan dengan hasil wawancara meliputi:

1) Kesesuaian alumni dengan bidang pekerjaan yang dijabat sekarang dan periode lama waktu untuk memperolehnya. Rata-rata sudah memberikan penilaian sudah terdapat kesesuaian bidang pekerjaan dengan lama periode waktu untuk memperoleh berkisar antara 6-8 bulan.

2) Penilaian tantangan \& hambatan alumni dalam penempatan bekerja di pabrik kelapa sawit dalam hal inisitiaf tindakan dan kepemimpinan (leadership) yang masih perlu ditingkatkan.

3) Masih diperlukan bimbingan dan arahan dari atasan atau senior orang pabrik dengan lama waktu bervariasi.

4) Rata-rata kemampuan umum/manajerial sudah baik, sedangkan kemampuan teknis alumni di pabrik sawit dikategorikan masih perlu ditingkatkan

\subsection{Luaran Penelitian yang Dicapai}

Adapun luaran penelitian yang diperoleh adalah:

1) Teridentifikasinya pola penyelenggaraan kerja sama antara pihak pemerintah, akademisi dan bisnis dalam penyediaan sumber daya manusia pengelola Pabrik Kelapa Sawit. Pola penyelenggaraan kerja sama yang telah dilakukan mencakup: (a)Proses rekrutmen dan tes penerimaan calon mahasiswa; (b)Penyusunan kurikulum pembelajaran; (c)Proses implementasi pembelajaran (pembekalan, kerja praktik, magang); (d)Penempatan kepastian bekerja di pabrik kelapa sawit dengan jabatan sebagai Asisten Pabrik.

2) Adapun tindakan teknologis yang diperlukan berkaitan dengan penyediaan SDM sawit nasional, di antaranya: (a)Masih diperlukan komunikasi dan koordinasi yang lebih intens agar kompetensi yang diminta pihak industri (pabrik kelapa sawit) dapat terpenuhi dengan baik; (b)Salah satu solusi untuk mengatasi butir (a) di atas adalah dibentuk wadah kelembagaan yang menghubungkan kepentingan industri dengan pihak akademisi (lembaga intermediasi); (c)Jenjang Diploma Tiga (D3) adalah jenis pendidikan vokasi, yang mengutamakan penguasaan aspek keterampilan (skill), sehingga atas dasar ini bobot praktik dan infrastruktur untuk melengkapi praktik ini harus tersedia dengan baik. 


\section{Kesimpulan}

ITSB sebagai salah satu aktor akademisi konsep triple helix telah berhasil ikut berperan dan berkontribusi dalam penyediaan SDM pengelola yang khusus menangani industri (specially dedicated to industry) perkelapasawitan nasional. Pola penyelenggaraan kerja sama yang telah dilakukan antara pihak Akademisi (ITSB) dan pihak Industri (No. Smart Tbk.), dibangun dari mulai aspek masukan (seleksi calon mahasiswa), penyusunan kurikulum, proses penyelenggaraan pembelajaran (implementasi kurikulum), praktik kerja lapangan dan magang industri serta jaminan bekerja dari industri.

\section{Ucapan terima kasih}

Ucapan terima kasih disampaikan kepada No. Smart, Tbk. yang telah menyediakan lokasi pabrik kelapa sawit untuk dikunjungi dan kesediaan para stafnya untuk dilakukan wawancara.

\section{Daftar pustaka}

[1] Afonso, Oscar; Sara Monteiro and Maria Thompson, "A growth model for the Quadruple Helix Innovation Theory", 2010.

[2] Carayannis EG, Campbell DFJ, "Mode 3 knowledge production in quadruple helix innovation systems. 21stCentury democracy, innovation, and entrepreneurship for development", 2012, Springerbriefs in business, Vol 7. Springer, New York.

[3] HD. Mulyaningsih, "Enhancing Innovation in Quadruple Helix Perspective: The Case of The Business Incubators in No.”, No. Conference on Global Trends in Academic Research, No. 2-3, 2014. GTAR (C2014 Bali, No. Global Illuminators, Kuala Lumpur, Malaysia.

[4] Buku Industri Minyak Sawit No. Menuju 100 Tahun NKRI: Membangun Kemandirian Ekonomi, Energi dan Pangan secara Berkelanjutan, Gabungan Pengusaha Kelapa Sawit No. (GAPKI) 2014.

[5] H. Darmadi, "Metode Penelitian Pendidikan", 2011, Penerbit Alfabeta Bandung.

[6] I. Hasan, "Analisis Data Penelitian dengan Statistik", 2010, Penerbit Bumi Aksara No.

[7] B. Lakitan, Pengembangan Sistem Inovasi Nasional No.: Kebijakan, Strategi, dan Upaya, 2009, Kementerian Negara Riset dan Teknologi.

[8] Sumber internet dengan alamat: http://juliharyono.wordpress.com/2012/01/06/sdm-perkebunan-sawit/ diakses pada tanggal 31 Agustus 2017.

[9] Zuhal, “Gelombang Ekonomi Inovasi”, 2013, edisi cetak online.

[10] Peraturan Pemerintah Republik No. No. 31 tahun 2006 tentang Sistem Pelatihan Kerja Nasional.

[11] Peraturan Presiden Republik No. No. 8 tahun 2012 tentang Kerangka Kualifikasi Nasional No. (KKNI).

[12] Peraturan Presiden Republik No. No. 28 Tahun 2008 tentang Kebijakan Industri Nasional.

[13] Peraturan Menteri Perindustrian No. 13/M-IND/PER/2010 tentang Perubahan atas Permenperin No. 111/MIND/PER/10/2009 tentang Peta Panduan (Road Map) Pengembangan Klaster Industri Hilir Kelapa Sawit.

[14] Peraturan Menteri Tenaga Kerja \& Transmigrasi No. PER.21/MEN/X/2007 tentang Tata Cara Penetapan SKKNI.

[15] Dokumen surat Rektor ITSB Nomor: 124/R/AK.01/VII/2011 tertanggal 27 Juli 2011.

[16] Dokumen Surat Mandat Direktur Jenderal Pendidikan Tinggi Nomor: 1079/E/T/2011, tanggal 28 Juli 2011.

[17] Dokumen SK Keputusan Mendikbud RI Nomor: 211/E/O/2012, tanggal 5 Juni 2012 tentang Penyelenggaraan Program Studi Teknologi Pengolahan Sawit (D-3) pada Institut Teknologi dan Sains Bandung di Bekasi. 